\title{
Figurative Meaning Used by Chairil Anwar on his Poetry 'Krawang- Bekasi'
}

\author{
Dhiana Fadjarwati \\ SMPN 41 Surabaya, e-mail: dhianafajar1071@gmail.com
}

\begin{abstract}
The purpose of this study is to describe the figurative meaning applied in the poetry written by Chairil Anwar "Krawang-Bekasi". This study was done by applying descriptive qualitative design by in the semantics theory supported by theory of figurative meaning proposed by Leech \& Short (1981). The instrument was the researcher as the primary instrument of the study. The data were examined into the description form within the poetry. The findings showed: (1) This poetry portrayed the war in Military Aggression I and II in Indonesia and described the story of the young soldiers Indonesia to grab Indonesia's independency; (2) Chairil Anwar also wrote the peace messages from the young dead soldiers who killed during the war. Chairil Anwar used alliteration and refrain to make a lyrical sound; used visual imagery, internal sensation imagery, and auditory imagery to involve the reader into the poetry. To broaden the reader's imaginations, Chairil used personification and symbol in case to illustrate the figurative meaning in the poetry.
\end{abstract}

Keywords: meaning, figurative meaning, poetry

\section{INTRODUCTION}

Basically, as means of communication, language is categorized into two forms called spoken language and written language. Chika (in Fitratunnas, 2017, p. 1) argued "The two forms of language is used to know and understand the interaction of human being based on their ideas or thought". Spoken language is known as an utterance in the form of sound such as daily conversation, discussion, speech, radio, television broadcast, and so forth. Meanwhile, written language is defined as an utterance which is formed in the written form such as comics, novels, poetries, newspapers, magazines, letters, and so forth.

Furthermore, Language is the human capacity for acquiring and using complex systems of communication, and language is any specific example of such a system (Tambunan \& Sinambela, 2018, p. 1). The scientific study of language is called linguistics. Language can be understood as relationship of sound and meaning. The discipline that studies linguistic sound is termed as phonetics, which is concerned with the actual properties of speech sounds and non-speech sounds, and how they are 
produced and perceived. The study of language meaning, on the other hand, is concerned with how languages employ logic and real-world references to convey, process, and assign meaning, as well as to manage and resolve ambiguity (Tambunan \& Sinambela, 2018 ).

In linguistics, semantics is well-known as one of linguistics branches which studies about language meaning or it can be said meaning as the primary study in semantics term. Meanings are classified as the ideas or concepts that can be transferred from the mind of the speaker to the mind of the listener by representing them as used in the form of one language or another. (Lyons, in Saputri, 2014, p. 14). Moreover, meaning is divided into two categories namely literal and no-literal meaning. Literal meaning is meaning formed by the speaker that has natural meaning or does not have other meaning (explicit meaning). Meanwhile, non-literal meaning is known as a meaning when the speaker says something that has different meaning of what his/her words or has hidden meaning (implicit meaning). Thus, the literal meaning can be studied as known in figurative language or figurative meaning.

Figurative meaning in language is a language that uses words or expressions with a meaning that is different from the literal interpretation. Figurative meaning has been widely examined by linguist in the study of literature in recent years. Figurative meaning is usually used in literary works, such as: speech, newspaper, poem, poetry, prose and nonfiction writing as well. In line with Kennedy (in Saputri, 2014, p. 15) argues that "Figurative meaning refers to words, and groups of words, that elaborate or modify the usual meaning in figures of the component of words". It can be said figurative meaning is the use of words that exceed their usual meaning.

Poetry, mostly composed in verse, is a written discourse. It is one of the effective forms of literature to express human ideas, emotions, reactions, responses, etc. (Regmi, 2014), "Poetry is a spontaneous overflow of powerful feelings recollected in tranquility". Poetry primarily is an expression of the state of human mind. Since poetry is often regarded as a medium for the expression of subjective, personal events an assumption which does not always correspond to the facts-the issue of the speaker is central to the analysis of poem. Poetry as one of the literary works is known as a genre of literature revealing the attractiveness and loveliness of human life and nature. 
Chairil Anwar, one of the Indonesian poets, is an artic person because he watched movie and theater every weekend in Medan and he would write the review. In addition, Chairil Anwar is literary works addict. He is also one of the members of the "1945 Generation” of writers (http://en.m.wikipedia.org). Chairil Anwar's poetry, Krawang-Bekasi, which was written in 1945-1948. This poetry talks about the idea which described and portrayed the inhumanity of war in Military Aggression I in Indonesia. This poetry was written by inspiration of The Young Dead Soldiers Do Not Speak which was written by Archibald MacLeish.

Chairil Anwar then published his work Krawang-Bekasi in 1949 in Jakarta. Chairil's work has so much in common with Archibald's so many critics assumed that he plagiarizes Archibald's work. In his work, Chairil Anwar put his own style so that it had different sense. This study was intended to describe and to describe the figurative meaning of poetry.

\section{METHOD}

This study was categorized as descriptive qualitative design. It is qualitative descriptive because the result of this study served in words form not in numeric form as quantitative method served. and this study was intended to describe and to describe the figurative meaning of poetry.

The primary data of this research is the poetry from famous poet in Indonesia written by Chairil Anwar entitled Krawang-Bekasi. The data were collected by reading Krawang-Bekasi, then tried finding the appropriate data from reading supporting books and googling the detail information in order to gain the understanding about the topic to interpret the figurative meaning within the poetry examined. The secondary data of this research is conduct through library research. In library research, it concerns in finding appropriate yet supporting reading sources and getting more reading sources by internet surfing. This is necessary because poetry and comparative literary study scholar are developed dynamically. Therefore, surfing the internet is necessary to find the more recent sources and information.

In the data procedure, the researcher started to go through the data more thoroughly and took down any notes for necessary explanations the collection of raw materials. This part involved underlining and highlighting important data as well as 
quoting from the poetry to provide concrete evidence. The data were selected and organized in accordance with the problem of the study so finally the writer can carry out an analysis. Then, all of the data examined were described in the form of description. Lastly, the researcher drew the conclusion based on the result findings.

\section{DISCUSSION}

Krawang-Bekasi is one of the last poems written by well-known poet of Indonesia, Chairil Anwar. This poem was published in 1949, in the year when Chairil Anwar passed away. This poem is portraying the horrific war in Indonesia especially in Karawang and Bekasi, in 1945-1949 (Han, 2015). In this poem, Chairil portrayed the horrific war by describing the situation along the road of Krawang and Bekasi. Here, he stated that there are many of Indonesian soldier's corps lying down on the road who killed during the battle between Indonesia and Dutch Army. Chairil Anwar recorded the horrific war, Military Aggression I and II on his poetry Krawang-Bekasi. Concerning to the figurative meaning within the poem, the researcher presented the discussion as follow:

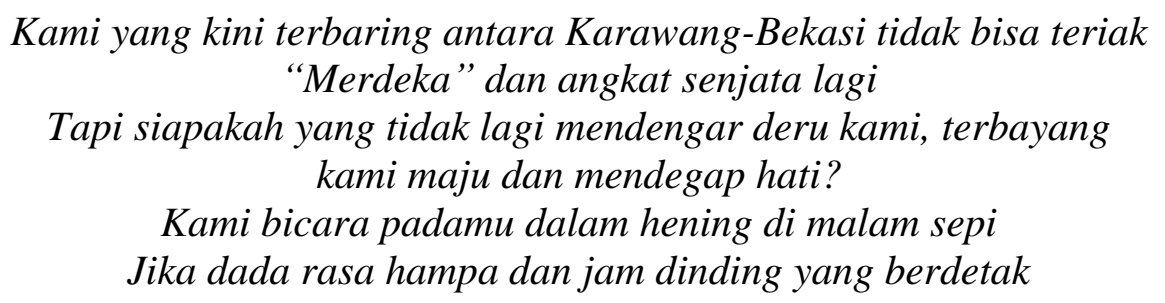

(Chairil Anwar)

In the opening of the poem, Chairil Anwar put the certain place where the poetry was set. He chose Karawang and Bekasi make the poem tastes locally. Chairil Anwar and his wife stay at Kawarang after their marriage and he travels from Karawang to Jakarta by passing Bekasi every day because he worked in Jakarta.

Kami mati muda. Yang tinggal tulang diliputi debu

Kenang, kenanglah kami

Kami sudah coba apa yang kami bisa

Tapi kerja belum selesai, belum bisa memperhitungkan arti 4-5 ribu nyawa

Kami cuma tulang-tulang berserakan

Tapi adalah kepunyaanmu

Kaulah lagi yang tentukan nilai tulang-tulang berserakan

Atau jiwa kami melayang untuk kemerdekaan

kemenangan dan harapan 
Atau tidak untuk apa-apa, Kami tidak tahu, kami tidak lagi bisa berkata

Kaulah sekarang yang berkata

(Chairil Anwar)

Chairil Anwar mentioned the supposition number of the young dead soldiers who killed during Dutch Military Aggression I and II in Indonesia and he maintained his characteristics, such as the figurative of a speech: atau jiwa kami yang melayang untuk kemerdekaan.

\section{Kami yang kini terbaring antara Karawang-Bekasi tidak bisa teriak "Merdeka" dan angkat senjata lagi}

(Chairil Anwar)

In the first line, Chairil Anwar used three symbols at once. They are kami, terbaring, and angkat senjata. The symbol 'kami' is symbolized animate thing, soldiers, because the next word in the sentence is followed by activities which are used by human being. Terbaring means the soldiers' corps who killed during the war at Karawang and Bekasi. While, angkat senjata means the soldiers cannot interfere to the battle field anymore because the soldiers had been killed.

The specific features of Chairil Anwar are often to shorten or eliminate affixes of verbs to make easiest pronounce and create rhythm. In this line, Chairil Anwar eliminates two prefixes in word bicara and angkat while that words should be written as berbicara and mengangkat. According to Bahasa Indonesia rule, the sentence in line 1 should be written as kami yang kini terbaring antara Krawang dan Bekasi tidak bisa berteriak "Merdeka" dan mengangkat senjata lagi. Although Chairil Anwar did not write his poem is not accordance to the rule of Bahasa Indonesia, but the two words in line 1 are not made change in meaning.

Tapi siapakah yang tidak lagi mendengar deru kami, terbayang kami maju dan mendegap hati?

\section{(Chairil Anwar)}

The second line in Krawang-Bekasi uses auditory imagery on deru and mendegap and visual imagery on maju. In this part, Chairil Anwar leaded the reader to imagine the sound of deru or familiar in English with thundering. Deru is produced by the sound of the weapon, tank, trucks, and air force. The word maju does not mean moving forward in to the front of class of podium but people will imagine the troops of 
Indonesia's army moving forward to break the enemy's defense. The last one is the word of mendegap will guide the reader to imagine about the sound of human heartbreak. The beat is getting faster because the troops have to move faster and faster to win the battle.

Kami bicara padamu dalam hening di malam sepi Jika dada rasa hampa dan jam dinding yang berdetak

(Chairil Anwar)

Here, Cahiril Anwar also insist the reader to broad their imagination. The word dalam hening di malam sepi used visual imagery and rasa hampa belongs to internal sensation imagery, and jam dinding yang berdetak belong auditory and visual imagery. Jam dinding yang berdetak belong to auditory and visual imagery because the clock count can be seen and heard.

When reading line 3 , the reader will imagine weather if the poet wants to deliver heavy messages or serious discussion because silent night refers to exclusive condition. Take to end marriage as an example. Parents will choose quiet and silent night as the best timing to talk to their children. It means quiet and silent night refers to serious and heavy talk. In addition, Chairil Anwar eliminates two prefixes in word bicara while that words should be written as berbicara.

\section{Kami mati muda. Yang tinggal tulang diliputi debu Kenang, kenanglah kami}

\section{(Chairil Anwar)}

In these two lines of poem contain four alliterations: kami mati muda, tinggal tulang, diliputi debu and kenang-kenanglah kami. There are three repetition exist in line 5: the sound of ' $\mathrm{m}$ ' in kami mati muda, sound of ' $\mathrm{t}$ ' in tinggal tulang, and the sound of ' $\mathrm{d}$ ' in diliputi debu. In line six, be present three repetition of the sound of ' $\mathrm{k}$ ' in Kenang, kenanglah kami. Sound repetition in lines of poem function is to give the effect more stress. In this poem, Chairil Anwar stressed the repetition of consonant in the beginning of the words is to combine the meaning of word and to give the color of music toward the poetry written.

Kami sudah coba apa yang kami bisa

Tapi kerja belum selesai, belum bisa memperhitungkan arti 4-5 ribu nyawa

(Chairil Anwar) 
In this line, Chairil Anwar asserted that he wanted to tell the reader that the soldiers had been trying their best on the battle. Then Chairil Anwar put the contrast of his statement in line 7 with the statement in line 8 . The soldiers had been killed before they win the battle and the number of the dead soldier still be counting because the battle had not been finished yet. In line 7, Chairil Anwar eliminate prefix in word coba while that words should be written as mencoba.

In line 8, Chairil Anwar added alliteration in belum bisa. The function of the alliteration in this line is to give the effect of beautiful sound color in the poem. While fighting against enemies' army during the First Military Aggression in Jakarta. The success of Indonesia's soldiers to kill the enemies seemed a good start to win the battle. He enemies in the batlle made an emergency landing after pounding Jakarta and surrounding areas to seize the rice barn and Dutch's plantation along Karawang and Bekasi Road. Yet, the soldiers who killed during the battle said that 4,000-5,000 did not means a lot because they cannot rise the victory flag and end the battle. In this line, Chairil Anwar eliminated prefix and suffix in kerja. In Bahasa Indonesia this word should be written as pekerjaan. The word kerja in this poem does not work or occupation but the battle between Indonesia and enemies' hands not been finished yet so the further generation of Indonesia should work harder to end the war.

Kami cuma tulang-tulang berserakan

Tapi adalah kepunyaanmu

Kaulah lagi yang tentukan nilai tulang-tulang berserakan

(Chairil Anwar)

In this stanza which contains three lines, Chairil Anwar tried to illustrate the pure hopes of the dead soldiers of Indonesia. The word tulang-tulang berserakan is the symbol of the dead soldiers. In these three lines, the soldiers hope the further generations of Indonesia remember them as the hero who fought for the independence of Indonesia although they could not win the battle yet. The hopes are truly portrayed in line 11 because the soldiers wanted to be honored by the further generation of Indonesia by define the meaning of the living lives during the war.

Atau jiwa kami melayang untuk kemerdekaan, kemenangan dan harapan

(Chairil Anwar) 
There is one symbol exist in his line: melayang. This symbol is stand for death. Here Chairil Anwar explained that the dead soldiers of Indonesia killed during the Military Aggression I and II. The soldiers are willing to die for the country in order to defend the independence of Indonesia which had just gained after fights for 350 years with Dutch colonialism. Their dead is expected to be an attempt to get the victory and hope for Indonesia's better future. In this line, Chairil Anwar also used alliteration of sound $\mathrm{k}$ in word untuk kemerdekaan kemenangan. The repetition of consonant in the beginning of the words is to combine the meaning of word and to give the color of music toward the poem.

Atau tidak untuk apa-apa,

Kami tidak tahu, kami tidak lagi bisa berkata

Kaulah sekarang yang berkata

(Chairil Anwar)

In this stanza, Chairil Anwar illustrated the hopelessness of the soldiers because they could not do anything and they had been killed during the war in Karawang and Bekasi in 1945 until 1949. In this line, the soldiers who died during the war hope that the further generation of Indonesia remember and honor them as the hero although they could not win the battle yet. That hopes were illustrated in line 15, kaulah sekarang yang berkata.

Kenang, kenanglah kami

Teruskan, teruskan jiwa kami

Menjaga Bung Karno

Menjaga Bung Hatta

Menjaga Bung Sjahrir

(Chairil Anwar)

These lines contain alliteration of sound of ' $\mathrm{k}$ ' in kenang-kenanglah kami and sound of " $\mathrm{t}$ " in teruskan, teruskan jiwa kami. In addition this poem contains repetition rhythm in the word kenang, kenanglah, teruskan, teruskan, and menjaga. The repetition of rhythm in the lines above confirms that the further generations of Indonesia have to remember and honor all the sacrifices that the late hero gave towards the independence of Indonesia. The five lines in this poem remind the further generations of Indonesia continue their spirit to protect Indonesia from foreign military and political attack. Chairil Anwar repeat the word menjaga three times in this poem. It means, the soldiers who killed during the war hope the further generation of Indonesia to look after the 
founding father of Indonesia: Soerkarno, Mohammad Hatta, and Sutan Sjahrir. The chosen of Soekarno, Mohammad Hata, and Sutan Sjahrir in this poem is because their contribution toward independence of Indonesia. In addition, these three figures who run the wheels of government in the early of independence of Indonesia in 1945.

\author{
Kami sekarang mayat \\ Berikan kami arti \\ Berjagalah terus di garis batas pernyataan dan impian
}

(Chairil Anwar)

In his poetry Krawang-Bekasi, Chairil Anwar many used repetition repetition of consonant sound and repetition of alliteration, to stress the meaning of the poem. This stanza is telling the reader that the dead soldiers of Indonesia remind the further generation of Indonesia to remember them as a hero. They said, their dead is because of they serve the country as a volunteer to fight colonialism of Dutch in Indonesia. In line 25 , the soldiers keep alert because the Dutch is one of tricky country in the world. Indonesia is often involved in civil war as a result of the politic of devide et impera by the Dutch government. Therefore, the dead soldier reminded again and again the further generation of Indonesia to keep in vigil and fight until the end of Indonesian independence can be achieved in full.

Kenang, kenanglah kami yang tinggal tulang-tulang diliputi debu Beribu kami terbaring antara Karawang-Bekasi

(Chairil Anwar)

This line contain two alliteration namely: alliteration of sound ' $\mathrm{k}$ ' in kenangkenanglah kami and sound ' $t$ ' in tinggal tulang-tulang. As usual the function alliteration in this poem is to make the beautiful sound when someone read the poem. Line 26 symbolized that the dead soldiers mean nothing because they cannot serve the country to fight in the battle field again. The sentence Kenang, kennaglah kami yang tinggal tulang-tulang diliputi debu repeat twice. It means in this poetry, Chairil Anwar seems so serious to deliver the messages of the dead soldiers to the further generation of Indonesia. In the last line in his poem, Chairil Anwar repeat the word berbaring for twice to symbolize that berbaring means passed away.

In his poetry Krawang-Bekasi, Chairil Anwar not only portrays the horrific war in the battle field but also the struggles of the Indonesian young troops in reaching independence. Krawang-Bekasi describes about the struggles of the young soldiers of 
Indonesia who killed during the war in Karawang and Bekasi where the military aggression took place in 1947-1948. In these lines, Chairil Anwar stated the poem is about the effort of Indonesia to declare her independency.

Chairil Anwar's ability in making lyrical sound and rhythm in his poem became one of his characteristics. If the readers read Chairil Anwar's poem loudly, they could hear the lyrical sound because Karawang-Bekasi contains alliteration and refrain. Although he is influenced by Archibald MacLeish directly but he still successes in maintaining his own characteristic. Poetry lover will recognize Chairil Anwar's poem directly because of his characteristic.

\section{CONCLUSION}

This study was done to answer the formulated problem in this study about the figurative meaning used in the poetry of Krawang-Bekasi written by Chairil Anwar which was written in 1945-1958. Chairil Anwar adapted Archibald MacLeish's poem entitled The Young Dead Soldiers Do Not Speak in the process of writing. This poetry portrayed the war in Military Aggression I and II in Indonesia and described the story of the young soldiers Indonesia to grab Indonesia's independency. Chairil Anwar also wrote the peace messages from the young dead soldiers who killed during the war.

Chairil Anwar succeed to maintain his characteristics, such as affixes elimination, grammatical structure, and lyrical sounds. Chairil Anwar wrote KrawangBekasi in the form of free verse of poetry. In Krawang-Bekasi, Chairil Anwar used alliteration and refrain to make a lyrical sound also used visual imagery, internal sensation imagery, and auditory imagery to involve the reader into the poetry. To broaden the readers' imaginations, Chairil Anwar used personification and symbol.

\section{REFERENCES}

Abrams, M. H. (1999). A Glossary of Literary Terms (7th ed.). New York: Cornell University.

Apriono, M. Y. (2017). An Analysis of Figurative Language used in the Lyrics of Scorpion Songs. Mataram: University of Mataram.

Fitratunnas. (2017). Figurative Language Analysis on Advertisement of the Jakarta Post Newspaper. Malang: universitas Islam Negeri Maulana Malik Ibrahim Malang. 
Han, E. S. (2015, May 16). https://id.linkedin.com/pulse/karawang-bekasi-karyachairil-anwar-eddy-sunandar-s-han. Retrieved from https://id.linkedin.com/pulse/karawang-bekasi-karya-chairil-anwar-eddysunandar-s-han

Leech, G. N., \& Short, M. H. (1981). Style in Fiction. London: Longman.

Regmi, L. R. (2014). Analysis and Use of Figures of Speech. Journal of NELHA Sukhet Vol.4, 76-80.

Saputri, E. E. (2014). An Analysis of Figurative Language Used in Rick Riordan's Novel Entitled "The Heroes of Olympics, Book Three: The Mark of Athena”. Semarang: Dian Nuswantoro University.

Tambunan, E. R., \& Sinambela, E. (2018 ). An Analysis of Figurative Meaning on Obama's Presidential Speech. The Episteme Journal of English Literature and Linguistics Vol 4 no $2,11$. 